The Philosopbical Journal of Conflict and Violence

Vol. III, Issue 2/2019

(C) The Authors 2019

Available online at http://trivent-publishing.eu/

\title{
Edmund Burke's Politics of Sympathy: Tolerance and Solidarity for India
}

\author{
Christos Grigoriou \\ University of Crete, Greece
}

\begin{abstract}
The article focuses on Burke's engagement with India and the Impeachment of Warren Hastings. It attempts to trace the way in which Burke, in his rhetoric on India, uses the sentimentalist vocabulary of the Scottish Enlightenment and, more particularly, the concept of sympathy. Burke, it is suggested, passes from a Humean to a Smithian understanding of sympathy, giving however, at every stage of this development, his own turn and character to the concept. Overall, Burke's writings on India denote political reflexes that are quite advanced for his time and oblige us to reconsider the stereotypical image of Burke as an icon of conservatism.
\end{abstract}

Keywords: David Hume; Adam Smith; India; Sympathy; Pity; Sublime; Tolerance.

DOI: 10.22618/TP.PJCV.20204.1.201001

The PJCV Journal is published by Trivent Publishing

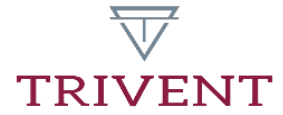

This is an Open Access article distributed in accordance with the Creative Commons Attribution Non Commercial (CCBY-NC-ND 4.0) license, which permits others to copy or share the article, provided original work is properly cited and that this is not done for commercial purposes. Users may not remix, transform, or build upon the material and may not distribute the modified material (bttp:/ / creativecommons.org/licenses/by-nc/4.0/) 


\title{
Edmund Burke's Politics of Sympathy: Tolerance and Solidarity for India
}

\author{
Christos Grigoriou \\ University of Crete, Greece
}

\begin{abstract}
The article focuses on Burke's engagement with India and the Impeachment of Warren Hastings. It attempts to trace the way in which Burke, in his rhetoric on India, uses the sentimentalist vocabulary of the Scottish Enlightenment and, more particularly, the concept of sympathy. Burke, it is suggested, passes from a Humean to a Smithian understanding of sympathy, giving however, at every stage of this development, his own turn and character to the concept. Overall, Burke's writings on India denote political reflexes that are quite advanced for his time and oblige us to reconsider the stereotypical image of Burke as an icon of conservatism.
\end{abstract}

Keywords: David Hume; Adam Smith; India; Sympathy; Pity; Sublime; Tolerance.

\section{Introduction}

With this article, I propose to bring out an aspect of Burke's political career and thinking for which there are yet many things to be written. ${ }^{1} \mathrm{I}$ am referring to Burke's engagement with India, the misrule of the East India Company and the misconduct of the Governor-General of India, Warren Hastings. ${ }^{2}$

\footnotetext{
${ }^{1}$ The work that exclusively treats Burke's engagement with the Indian affairs is Frederick G. Whelan's, Edmund Burke and India: Political Morality and Empire (Pittsburgh: University of Pittsburgh Press, 1996). An especially favorable account of this aspect of Burke's political career is given by U.S. Mehta in Liberalism and Empire (Chicago and London: The University of Chicago Press, 1999) and also by Gibbons in Edmund Burke and Ireland (Cambridge: Cambridge University Press, 2003). Gibbons's interest, as it is manifest by his title, is broader and links Burke's writing on India with his experiences in Ireland. A special mention is required for the work of Richard Bourke, Empire and Revolution (Princeton: Princeton University Press, 2015). Bourke's treatment of Burke's engagement with India is notably extended and minute. Moreover, Bourke takes Burke's attempt to arouse the pity and sympathy of his audience as a crucial element of his rhetoric on India, thinking, however, that he uses a concept of pity influenced by Anglican moralists such as Tilloston. Bourke relates sympathy and pity to Christian charity. Without denying that such an approach can be found in Burke's speeches, my argument is that in his Indian speeches Burke uses also sympathy as a psychological mechanism and, in this context, implicitly converses with the representatives of Scottish Enlightenment. In fact, Bourke pursues this comparison in relation to the quality of Beauty. On Burke's engagement with India, see also the broader thematic biography of Cruise O' Brien, The Great Melody (Chicago: University of Chicago Press, 1992) and the relevant chapter on Suleri's, The Rhetoric of English India (Chicago and London: The University of Chicago Press, 1993) which places a special interest in Burke's engagement with India.

2 The East India Company was founded in 1600 as a commercial company with a monopoly of British trade with India. By its involvement in Indian wars, it became the ruler of extensive Indian territories and it transformed itself into a major military and political power that controlled many nominally
} 
Burke's writings on India are of special importance for two major reasons: for their contribution to political theory in general and their place in Burke's political career and thought more particularly.

As to the first, these writings deal with a relatively neglected aspect of political theory, that is with empire and the relation between the metropolis with its subject states, Burke, as Whelan observes, "was one of the first major European thinkers, and one of the few writers in the traditional canon of Western political theory, to have made a serious effort to understand a non-Western civilization and to incorporate his findings into his general political thought." ${ }^{3}$ As to the second, it is noteworthy that, although Burke owes his reputation to the attack on the French Revolution, his wish was to be remembered for his defense of the people of India. Concluding in the Reflections on the Revolution in France, Burke thought it proper to say that "the hours he has employed..." on the Revolution in France he "snatches (them) from his share in the endeavors which are used by good men to discredit opulent oppression..."4 Burke indeed devoted an extremely long period of his life occupied with the Indian affairs. His involvement started with the beginning of his political career, in 1767, and ended in 1795, after the acquittal of Warren Hastings, two years before his death.

My purpose with regard to Burke's writings on India is relatively modest and focused. Far from attempting to evaluate his overall attitude towards empire, or even India, and the different languages he uses (the language of rhetoric, of Natural Law ${ }^{5}$ and Christian charity), I am only interested in the way Burke adopts and applies to politics the sentimentalist tradition of the Scottish Enlightenment and, more particularly, the concept of sympathy. In this context, the aim of this article is to reconsider the stereotypical image of Burke as an icon of conservatism, without, however, exaggerating his progressivism. ${ }^{6}$ In short, I restrict myself to Burke's writings on India and, from these, to his direct or indirect references to sympathy and I wish to bring out a progressive feature of Burke's traditionalism, avoiding, at the same time, anachronisms that would make Burke an anti-imperialist hero.

The plan of this article is the following: I start with a section on Burke's A Philosophical Enquiry into the Origin of our Ideas of the Sublime and Beautiful, where the most systematic treatment of the concept of sympathy is to be found. In this context, I attempt to reconstruct Burke's theoretical treatment of the concept of sympathy, using Hutcheson's, Hume's and Smith's concepts of sympathy as a sort of typology to different kinds of sympathy. I then proceed with passages taken from Burke's Speeches on the Impeachment of Warren Hastings and the Speech on Fox's East India Bill (1783), trying to capture the way Burke gives sympathy a political turn and significance and how this formulates his imperial political vision. I conclude this

independent states. It was only after 1773 that Burke and the Whigs gradually understood that the company was in fact abusing political power.

${ }^{3}$ Frederick G. Whelan, Edmund Burke and India, 5.

${ }^{4}$ Edmund Burke, The Writings and Speeches of Edmund Burke (Oxford: Oxford University Press, 1998), VIII, 293.

${ }^{5}$ Burke's India Speeches have often been cited as evidence of his attachment to the classical Natural Law tradition. This interpretation, which presents Burke as a Natural Law thinker, was introduced by Leo Strauss in Natural Right and History (Chicago: The University of Chicago Press, 1953). Strauss's interpretation spread in America after the Second World War, when several thinkers placed Burke in the tradition of Aristotle, Cicero and Aquinas. See for instance Russel Kirk, Edmund Burke: A Genius Reconsidered (Arlington House, New: Rochelle, 1967), Peter J. Stanlis, Edmund Burke and the Natural Law (Ann Arbor: University of Michigan Press, 1958) and Francis Canavan, The Political Reason of Edmund Burke (Durham: Duke University Press, 1960).

${ }^{6}$ For a criticism of this presentation of Burke's imperial politics, see Margaret Kohn and Daniel I. O'Neill, "A Tale of Two Indias: Burke and Mill on Empire and Slavery in the West Indies and America," Political Theory, 34/ 2 (2006): 192-228. 
article with a rather sketchy attempt to compare Burke's rhetoric on India with his rhetoric on the French Revolution, focusing on the Marie Antoinette passage.

\section{Sympathy, Pity and Redress}

Attempting then to reconstruct Burke's understanding of the concept of sympathy in the Enquiry, let me start by pointing out the fact that Burke was well acquainted with the Scottish Enlightenment and explicitly favored its sentimentalist orientation. The title itself of the work seems to refer to Hutcheson's An Inquiry into the Original of our Ideas of Beauty and Virtue of 1725 and, besides, in the introduction "On Taste," that he added in its second edition of the work, in 1759 , we come upon another indirect reference to Hutcheson. ${ }^{7}$ Furthermore, Burke reviewed Smith's Theory of Moral Sentiments in the Annual Register of 1759, praising highly the work. "The author," he wrote, "seeks for the foundation of the just, the fit, the proper, the decent, in our most common and most allowed passions; and making approbation and disapprobation the tests of virtue and vice, and shewing that those are founded on sympathy, he raises from this simple truth, one of the most beautiful fabrics of moral theory, that has perhaps ever appeared." 8

As Burke's Enquiry and Smith's Theory of Moral Sentiments, however, have the same date of publication (1757), and, according to Burke himself, the Enquiry was completed many years before, ${ }^{9}$ most probably Burke did not form his concept of sympathy under the influence of Smith. ${ }^{10}$ In fact, I will suggest that in the Enquiry Burke is influenced by the Humean understanding of the concept, although there are important points of divergence between him and Hume.

In Burke's Enquiry, then, the concept of sympathy is introduced as one of the three basic links of society, but it is in fact used by Burke to explain first the pleasure we get from tragedy and, secondly, the influence that "descriptive" (that is, not dramatic) poetry exerts.

Burke defines sympathy "as a sort of substitution, by which we are put into the place of another man, and affected in many respects as he is affected." 11 He describes an identification that regards the sentiments of another person and there is nothing yet relating to the circumstances that gave rise to them. Burke's first sentence in the section on sympathy leaves, indeed, no room for doubts about the Humean understanding of his concept of sympathy. Through sympathy, he writes, "we enter into the concerns of others... we are moved as they are moved, and are never suffered to be indifferent spectators of almost anything which men can do or suffer." 12

\footnotetext{
${ }^{7}$ Discussing whether taste must be considered as a separate faculty, Burke observes that "to multiply principles for every different appearance, is useless, and unphilosophical too in a high degree." See Edmund Burke, The Writings and Speeches of Edmund Burke, I, 209.

${ }^{8}$ See Annual Register for the year 1759.

${ }^{9}$ In the introduction of the first edition of the Enquiry, Burke informs us that the project had already been completed four years earlier and we have clues that Burke's interest in the subject goes back still further. See Richard Bourke, Empire and Revolution, 146-147.

10 The other way around is more probable, as we have a reference to Smith's admiration for Burke's work. See James Prior, Life of Edmund Burke (London, 1826), 38n. We do not know, however, when Smith read the Enquiry.

11 Ibid., 220-221.

12 "No quality of human nature is more remarkable," Hume writes, "both in itself and in its consequences, than the propensity we have to sympathize with others, and to receive by communication their sentiments, however different from, or even contrary to our own." David Hume, A Treatise of Human Nature (Oxford: Clarendon Press, 1978), 316.
} 
Burke thus gives sympathy the character of a neutral mechanism of the imagination, which gives us access to all the passions of others, either pleasurable or painful. ${ }^{13}$

In this context, sympathy for Burke may work as a source of both the sublime and the beautiful. It allows us to partake in sentiments of both pleasure and pain. Burke's focus, however, in contrast with Hume's major interest, is on sympathy with pain and distress, leading thus to the quality of the sublime. Sympathy, as we have already said, is first introduced to explain the pleasure that comes from watching the painful scenes of tragedy and, in this context, is closely related to the concept of pity. In fact, Burke reworks the Aristotelian dipole of pity and fear. ${ }^{14}$

The problem of sympathy with distress is that normally it should make us shun scenes of misery, since it is a painful experience. It is in his attempt to face this difficulty that Burke's analysis becomes the most original. He contends that the partaking in the pain of others, provided we are safe and watch from a distance, is someway pleasurable; that it causes, in Burke's terminology, delight, a special pleasure coming from pain. "Terror," he writes in one of the most controversial formulations of the Enquiry, "is a passion which produces delight, when it does not press too close, and pity is a passion accompanied with pleasure, because it arises from love and social affection." 15 Delight, however, is a mixed passion and blended with a strong sense of uneasiness. This uneasiness, according to Burke, drives us to intervene and redress the suffering in order to relieve ourselves from it. Thus, we come to a paradox: the urge to redress pain comes from the principle of self-preservation and not from that of society.

Let us also notice that the connection of the spectacle of pain with delight is attributed by Burke to a divine providence. "As our Creator has designed we should be united by the bond of sympathy," Burke writes, "he has strengthened that bond by a proportionable delight; and there most where our sympathy is most wanted, in the distresses of others." 16 In this, Burke deviates crucially from Hume, who introduced sympathy to avoid any teleological presupposition in his system. Burke, however, does not fall back to Hutcheson. While Hutcheson's ultimate aim is moralistic, as he intended to relate taste to virtue, Burke chooses to separate the two in the most radical way, ${ }^{17}$ giving to his analysis some interesting social and political connotations. If pity, he writes, "was simply painful, we would shun with the greatest care all persons and places that could excite such a passion; as, some who are so far gone in indolence as not to endure any strong impression actually do. But the case is widely different with the greater part of mankind." 18 Human nature in itself, from its very constitution, drives man to pity; civilization and social or political power, however, sometimes corrupt this natural tendency. In addition, behind the choice of the words "indolence" and the "greater part" we can decipher a division between a social and political elite and the great majority of the population in either Great Britain, Ireland, or India.

13 This description of sympathy refers to the capacity that psychology would later call empathy. See Stephan Darwall, “Empathy, Sympathy, Care," Philosophical Studies 89/2-3 (1998): 261-282. Darwall takes Hume to be a major reference for sympathy understood in terms of a contagion of passions.

${ }^{14}$ Hume had also treated pity, defining it as "a concern for ...the misery of others, without any friendship to occasion this concern." See David Hume, A Treatise of Human Nature, 369). He attributed the passion to the working of sympathy, and it is noteworthy that he too linked it to tragedy's impact.

${ }^{15}$ Edmund Burke, The Writings, I, 222.

16 Ibid.

17 "From what has been said in the foregoing section," he writes, "we may easily see, how far the application of beauty to virtue may be made with propriety. The general application of this quality to virtue, has a strong tendency to confound our ideas of things and it has given rise to an infinite deal of whimsical theory." Ibid, 272.

${ }^{18}$ Ibid., 222. The emphasis is mine. 
In Burke's analysis concerning sympathy, there is a quite interesting and important fusion of real with fictive sympathy. To explain the impact of tragedy, Burke tries to see the way real affliction and suffering affect us. Most importantly, Burke suggests that real sympathy is stronger than fictive. The paradigm concerning the execution of a notorious criminal is well known and quite eloquent.

Chuse a day on which to represent the most sublime and affecting tragedy we have; ... and when you have collected your audience, just at the moment when their minds are erect with expectation, let it be reported that a state criminal of high rank is on the point of being executed in the adjoining square; in a moment the emptiness of the theatre would demonstrate the comparative weakness of the imitative arts, and proclaim the triumph of the real sympathy. ${ }^{19}$

We now come to the way Burke treats sympathy in the fifth chapter of the Enquiry, where he discusses the effect of words and, accordingly, the power of rhetoric and poetry upon our emotions and opinions. "We take an extraordinary part in the passions of others," he observes, "and we are easily affected and brought into sympathy by any tokens which are shewn of them; and there are no tokens which can express all the circumstances of most passions so fully as words; so that if a person speaks upon any subject, he can not only convey the subject to you, but likewise the manner in which he is himself affected by it." 20 Once more, Burke adopts Hume's understanding of sympathy as a contagion of passions, ${ }^{21}$ and we may guess that Burke has also in mind something like the Humean mechanism through which external signs communicate the idea of someone's passions, and then, following the principles of contiguity and resemblance, this idea is transformed into an impression and causes the passion itself.

Burke's emphasis, however, is placed on the idea that words do not affect us by representation; by the formation, that is, of clear ideas in our minds. He contends instead that they operate through the connection of a sound with a certain sentiment and, furthermore, he proceeds to the radical claim that words can affect us even without referring to any content whatsoever, thus subscribing to a radical nominalism. ${ }^{22}$ "It is hard," he maintains, "to repeat certain sets of words, though owned by themselves unoperative, without being in some degree affected, especially if a warm and affecting tone of voice accompanies them, as suppose, wise, valiant, generous, good and great. These words, by having no application, ought to be unoperative; but when words commonly sacred to great occasions are used, we are affected by them even without the occasions." 23 This is a clear reference to the power of rhetoric in steering public opinion and creating moral sentiments at will. Accordingly, Burke brings several examples from the field of poetry and the power that the connection of certain moving words may have upon us; a power that, far from coming from clarity of representation, is increased with the obscurity of the formulations.

Thus, we come to the passage from which we started, the passage referring to the easy communication of sentiments through sympathy. Not only do words present sentiments and subjective opinions, but also these, thanks to sympathy, have a very easy access and potent impact on others, who readily adopt them. What is of special importance, furthermore, is that

\footnotetext{
19 Ibid., 223.

20 Ibid., 317.

21 "By the contagion of our passions," Burke writes, "we catch a fire already kindled in another". Ibid, 319.

22 See David Bromwich, The Intellectual Life of Edmund Burke, 99.

23 Edmund Burke, The Writings, I, 311.
} 
the person using affecting words, even without having any idea of their actual content, ends up being affected himself. Burke brings the example of Blacklock, a poet blind from birth, who managed to affect his audience, through the description of visible objects he had never seen, and who, furthermore, was "as much affected by his own descriptions as any that reads them." 24

A final comment relating to the passage with which we started is important. I maintain that, when Burke writes that "we take an extraordinary part in the passions of others," 25 we must take the adjective "extraordinary" very seriously. Hume and Smith thought that the idea of self was always predominant and posed insurmountable barriers to our sympathetic identification with others. ${ }^{26}$ For Burke, on the other hand, sympathy can indeed allow us to transcend our individuality. As he puts it, "our minds and bodies are so closely and intimately connected, that one is incapable of pain or pleasure without the other." 27 This association allows us to literally feel another person's pain. Bringing the example of the physiognomist Campanella, Burke observes that we can feel another person's sentiments just by simulating his expressions. ${ }^{28}$

\section{Sympathetic Sublime and Cross-Cultural Solidarity}

The purpose of this section is to inquire into the way Burke's aesthetic work informs his political one and, particularly, his speeches on India. Taking up the threads of the previous analysis on the power of words, I am suggesting that Burke applies this insight to India. The theorist of aesthetics becomes in this new context the political orator who, by his ardent speeches, attempts to affect his audience. Burke knows that persuasion has its rules and techniques, in the application of which he was one of a kind. Rhetoric, however, was not just a show, a competition of eloquence. The choice of a pathetic style was not just the easy way to cause sympathy. Burke, in fact, considered it his duty to use passionate language. Solidarity and care for the distressed demanded, he thought, a sincere and deeply felt passion, expressed in a pathetic rhetorical style..$^{29}$ "A cold style of describing actions which appear to me in a

\footnotetext{
24 Ibid., 313.

25 Ibid., 317.

${ }^{26}$ Nothing is so mortifying as to be obliged to expose our distress to the view of the public, and to feel, that, though our situation is open to the eyes of all mankind, no mortal conceives for us the half of what we suffer." Adam Smith, The Theory of Moral Sentiments (London: H. G. Bohn), 70.

${ }^{27}$ Edmund Burke, The Writings, I, 286.

28 "This man," Burke observes, “... had not only made very accurate observations on human faces, but was very expert in mimicking such, as were any way remarkable. When he had a mind to penetrate into the inclinations of those he had to deal with, he composed his face, his gesture, and his whole body, as nearly as he could into the exact similitude of the person he intended to examine; and then carefully observed what turn of mind he seemed to acquire by this change. So that, says my author, he was able to enter into the dispositions and thoughts of people, as effectually as if he had been changed into the very men." Ibid.

${ }^{29}$ Commenting on the performance of Gilbert Elliot, who one year earlier, in December 1787, had opened the proceedings against Elijah Impey, Burke extolled his oratory: "his method," he wrote, "the arguments, the sentiments, the language, the manner, the action, the tone and modulation of voice were all exactly of a piece." See Edmund Burke, The Correspondence V, 369. Besides, however, the masterly use of technique, Burke noted that what was mostly needed was sincerity. "In truth the whole came from the heart, and went to the heart," he went on "sincerity was a prerequisite for evoking proper sympathy." (Ibid.). It goes without saying that this was also the way he understood his own role as a speaker in the parliament.
} 
very affecting light," he writes in his Speech on Fox's East India Bill, "is equally contrary to the justice due to the people, and to all genuine human feeling about them." 30

This is not all, however, because Burke attempts to arouse the sympathy and pity of the Lords for the people of India not just through a passionate rhetoric, but also through the "thunderbolt" of the sublime; by staging, that is, a shocking and quite "impolite" performance at the very heart of the polite world, the House of Lords. I am referring to Burke's treatment of the punishments inflicted upon the population of Rungpore and Dinagepore for not paying the taxes demanded. Burke's introduction to his speech is telling: "My Lords, I am obliged to make use of some apology for the horrid scenes that I am now going to open to you... You have had perhaps more than enough, of oppressions upon property and oppressions upon liberty, but here the skin was not touched... The punishments inflicted upon the Ryots, of both Rungpore and Dinagepore for non-payment, were in many instances of such a nature, that I would rather wish to draw a veil over them than shock your feelings by the detail." 31 This is exactly, however, what Burke does. He completely rips the veil of discretion and decorum and, with an almost sadistic insistence on details, he proceeds to describe the horrific tortures inflicted on the natives. It is worthwhile, I think, to site a relevant abstract:

The first mode of torture was this. They began by winding cords about their fingers until they had become incorporated together, and then they hammered wedges of wood and iron between those fingers until they crushed and maimed those poor, honest, laborious hands...They began there, but there they did not stop. The Heads of villages, the parochial Magistrates, the leading Yeomen of the country, respectable for their situation, and their age, were taken and tied together by the feet, two and two, thrown over a bar, and there beaten with bamboo canes upon the soles of their feet until their nails started from their toes. And then, falling upon them, while their heads hung down as their feet were above, with sticks and cudgels, their tormentors attacked them with such blind fury that the blood ran out of their mouths, eyes and noses. This was the second step that they took with these unfortunate people. ${ }^{32}$

Why these lucid details? In the Enquiry, Burke had argued for a very close association between mind and body, suggesting that our imagination can indeed produce real physical reactions. This imagination Burke attempts to feed with his graphic description of the atrocities committed against the natives. He does not rest at the general benevolence and humanity of his audience. He is not content with some tears of compassion, which would just reaffirm the distance between sufferer and spectator. He wants to produce so lively a picture of the sufferings as to cause to his audience something very close to the actual pain of the sufferers. He wants to unsettle the people hearing him and cause them real uneasiness. The delight they take from the exposition to a pain which does not affect them directly will keep them in the House eager to hear more, the uneasiness produced by the atrocities will drive them to action; it will drive them to relieve the sufferers in order to relieve themselves. The physical resemblance of all human beings, the fact that bodily pain is common to all and comes from the same causes, allows Burke to rely still on a Humean kind of sympathy.

In the description of the suffering of the people of India, however, besides the graphic details, there is something else that needs stressing. This is the fact that Burke does not restrict himself to physical pain, nor does he consider this form of pain to be the most intense. Burke

\footnotetext{
${ }^{30}$ Edmund Burke, Speech on Fox's East India Bill, 126. The pages for this work refer to the Liberty Fund Edition (Indianapolis, 1999).

${ }^{31}$ Edmund Burke, The Writings, VI, 420.

32 Ibid.
} 
starts with the physical tortures only to climax his rhetoric with the assault on the mind, the sensitivities and then the dignity of the sufferers. Burke describes how "innocent children were brought out and scourged before the faces of their parents," 33 how virgins were violated publicly and how the Brahmins were "put upon a bullock, and with drums beating... (were) driven through the country." ${ }^{34}$ Both of them, he concludes, lost their caste and with that "all their community of life." 35

In the above-cited references, we find an important differentiation of pain, which corresponds, as well, to a certain dualism of human nature. On the one hand, we have the physical pain and, on the other, the mental; the one arises from violence exerted on our bodies, the other from violence exerted on our opinions and relevant sentiments. For Burke, the second kind of pain is more acute and lasting. "Man," he writes, "is made of two parts the physical part and the moral. The physical parts suffer famine, distress, violence, outrage, but disgrace, shame, violation of manners, violation of opinions, injury to inborn sentiments of people, made doubly forcible upon them by the manners and usages which is the second nature of their country." 36 While the pains of the body address our common humanity, the violence against established habits, manners and prejudices, touches difference and cultural specificity.

This is the immense difficulty that Burke's venture to arouse pity must face. Burke realizes that cross-cultural sympathy is extremely difficult to accomplish, because the two basic principles that Hume linked to sympathy, that is resemblance and contiguity, were completely missing in this case. The Indians, in fact, represented for the British not only the utterly different and alien, but also the inscrutable, that which is not penetrable by understanding and reason. ${ }^{37}$ Burke summarizes the gulf which separates the two civilizations with the following words:

we are in general...so little acquainted with the Indian details, the instruments of oppression under which the people suffer are so hard to be understood and even the names of the sufferers are so uncouth to our ears, that it is very difficult for our sympathy to fix upon these objects. ${ }^{38}$

This lack of familiarity and understanding Burke had already tried to address in his Speech on Fox's East India Bill. ${ }^{9}$ 'There, with the objective of familiarizing the British to the Indian civilization, Burke adopts a cold and descriptive style. He presents the extent of the territories under British dominion; he refers to the magnitude of the native population and mostly to its quality, to its social stratification and diversity. He refers to "princes once of great authority and opulence," to "chiefs of tribes and nations," to "an ancient and venerable priesthood," to "a nobility of great antiquity and renown," to "merchants and bankers," to "manufacturers and mechanics," to "tillers of the earth." ${ }^{40} \mathrm{He}$ comments on the civilization and cultivation of India and mentions the different religions that were to be found in this vast area (Burke refers to the "Bramincal", to the "Musselmen" and to the Eastern and Western Christians).

\footnotetext{
${ }^{33}$ Ibid.

${ }^{34}$ Ibid., 425.

35 Ibid.

${ }^{36}$ Edmund Burke, The Writings, VII, 540.

37 On the way the British looked at the Indian civilization and especially the on way in which liberal thinkers treated the empire, see Uday Singh Mehta, Liberalism and Empire (Chicago: University of Chicago Press, 1999).

${ }^{38}$ Edmund Burke, Speech on Fox's East India Bill, 108.

${ }^{39}$ East India Bill was an initiative of the Fox-North governmental coalition for bringing the government of India under the control of the Parliament.

${ }^{40}$ Ibid., 107.
} 
In short, in India Burke saw not barbarous and uncultivated tribes, but a "people for ages civilized and cultivated; cultivated by all the arts of polished life, whilst we were yet in the woods." ${ }^{11}$ Burke thus treats the Indian society as an organized whole, as a complex, mature and richly diversified social organization with its variety of orders and classes, with its laws, religion, manners, usages and of course governments. Thus, trying to understand and, in turn, to explain it, he is in fact attempting to reconstruct India's political and cultural identity through time.

In the above approach, we have undoubtedly another token of Burke's traditionalism, which vindicates the political arrangements that have survived through time, producing a complex social and political structure beneficial to society. In our context, however, this traditionalism takes a notably progressive character, since the very existence of such an order and identity was at the $18^{\text {th }}$ and even at the $19^{\text {th }}$ century questionable. In fact, the long liberal tradition that stemmed from Locke and culminated with the Mills, disclaimed such a collective identity. For these theorists, the Indians were immature, both on an individual and on a civilizational level. They were considered more like children in need of tutoring; and, of course, the tutor was supposed to be no other than imperial England. For such a tutelage indeed, despotism might be adequate, as democratic institutions were fit only for mature men. ${ }^{42}$ Burke's traditionalism in India, on the other hand, not only is it a token of respect and tolerance, but it also tends to humble his audience.

To crown the above description, in order to make India even more familiar to his audience, Burke ends up with a telling analogy. He compares India to Germany:

It is an empire of this extent, of this complicated nature, of this dignity and importance, that I have compared to Germany and the German government; not for exact resemblance, but as a sort of middle term, by which India might be approximated to our understanding, and if possible to our feeling, in order to awaken something of sympathy to the unfortunate natives, of which I am afraid we are not perfectly susceptible, whilst we look at this very remote object through a false and cloudy medium. ${ }^{43}$

Since the British differ utterly from the Indians, an immediate communication of sentiments cannot work on the level of civilization; cross-cultural sympathy seems unattainable, at least in Humean terms. If the Commons, however, to whom this speech is addressed, could imaginatively reconstruct — or have reconstructed for them - the alien civilization and thus place themselves in the situation of the Indians; if they could think and feel as the Indians think and feel, then sympathy, in Smithian terms this time, could probably be hoped for. In other words, the appeal to understanding in the passage quoted bespeaks, in my opinion, a gradual absorption by Burke of the Smithian perspective of sympathy. The concept does not describe any more a spontaneous and automatic process, an easy contagion of passions, but presupposes a conscious and quite complex process of reconstruction and evaluation.

Despite Burke's indisputable eloquence and the unflagging efforts to acquaint his audience to India, sympathy's natural partiality and parochialism, was meant to prove an insurmountable obstacle. In fact, Burke seems to foretell the final acquittal of Hastings when he observes:

${ }^{41}$ Ibid.

${ }^{42}$ See Uday Singh Mehta, Liberalism and Empire.

${ }^{43}$ Ibid., 108. 
we hold it the greatest of all crimes to bestow upon the oppressions that pity which belongs to the persons that are oppressed. People that are wronged, people that are robbed, people that are despoiled have no other remedy but the sympathies of mankind and when these sympathies are suffered to be debauched, when they are carried from the sufferer to the person that injures them, we commit a robbery still greater than the robbery committed by the other person. ${ }^{44}$

\section{Towards a "Sympathetic" Imperial Rule}

The adoption of the Smithian perspective by Burke is also ascertained by the use of the concept of sympathy in relation to justice. Sympathy for Burke is designed to drive men to intervention for redress. In the political context, the sympathy that Burke tries to awaken in the hearts of the Lords is designed to drive to justice and, more particularly, to the indictment of Warren Hastings. As it is through sympathy therefore that Burke attempts to activate the Lords, he does not hesitate to use for justice the phrase "sympathetic revenge." It is a revenge, he explains, "regulated but not extinguished, transferred from the suffering party to the communion and sympathy of mankind." 45 The characterization of justice with the term revenge gives it a quasi-personal character and surely engrafts its working with strong emotionality. ${ }^{46}$ Sympathy, on the other hand, both feeds and prescribes this emotionality. The members of the parliament seem in fact to take a role analogous to the Smithian impartial spectator; observing from a considerable distance, they are more impartial than the sufferers, but, thanks to the spontaneous working of the human nature and of course to the artistry of the speakers, they are also far from unaffected. It is noteworthy that Aristotle too gave justice a personal character, but, for this, he argued for a limited population for his ideal state. ${ }^{47} \mathrm{In}$ the imperial context, Burke seems to consider sympathy as capable of transforming even empire into a community of sentiments.

To the difficulties of this venture, we have already referred, and we have already referred to Burke's attempts to bring India close to the British and awake their sympathy. The victims however must also contribute their share. In contrast with Smith, who demanded from the sufferers to moderate their pain, showing a stoical equanimity and self-restrain, to gain the sympathy of an impartial spectator, Burke calls the victims to do exactly the opposite; to revolt against injustice and express their pain. 48 "The people of India," he observes, "are patience itself, their patience," however, is "too criminal."49 A letter of Burke, although referring to incidents that took place in Ireland, is expressly applicable to our case too: "all the miseries have originated, in what has produced all the miseries in India, a servile patience under oppression, by the greatest of all misnomers called prudence." 50 The political and, much more, the imperial context demand, for Burke, loud protest, complaint and even resistance, because otherwise the victims of injustice and cruelty will remain forever invisible.

\footnotetext{
${ }^{44}$ Ibid., 247.

45 Edmund Burke, The Writings, VII, 247.

46 A quite intriguing subject of further inquiry would be to relate these characteristics attributed to justice by Burke to the way the British legal system actually worked and to the role of the two parliaments in it.

47 Aristotle, Politics, 1326a 25-1326b 11.

${ }^{48}$ Edmund Burke, The Writings, VI, 422. The call for expression of one's feelings and the condemnation of a stoical attitude towards pain, would also characterize Burke's personal life. See Luke Gibbons, Edmund Burke and Ireland (Cambridge: Cambridge University Press, 2003), 102-104.

${ }^{49}$ Ibid..

${ }^{50}$ Edmund Burke, The Correspondence, VIII, 147.
} 
Referring to the British officials that were taking advantage of British rule in India, he wrote; "their prey is lodged in England, and the cries of India are given to the seas and winds." 51

The call to the victims of imperial rule to protest and resist tyrannical power, coming from the philosopher of prudence and moderation, the later icon of conservatism, is impressive ${ }^{52}$ and, along with Burke's demand for "sympathetic revenge," bespeak a militant commitment in favor of the sufferers; a true sense of solidarity that transcends national and even racial boundaries. ${ }^{53}$ Besides, in the context of his descriptive rhetoric, Burke exhibits a remarkable open-mindedness and an impressively liberal attitude towards the communities under his focus. His advocacy, however, is neither for abstract democratic rights for the people of India nor for self-rule and independence, but for a "sympathetic" rule. "The natives," he observes, "scarcely know what it is to see the gray head of an Englishman. Young men (boys almost) govern there without society and without sympathy with the natives. They have no more social habits with the people, than if they still resided in England." 54

Burke, more particularly, presents the British conquest in marked antithesis with the Islamic one; and this comparison, surprisingly or not, turns in favor of the latter. The Asiatic conquerors, he observes, after having accomplished their conquest, settled in the new land and created bonds with the place and the people. They reconciled themselves with the object of their conquest, taking an interest in the place and growing sentiments for its inhabitants. In a word, they made the conquered country theirs and they associated its prosperity with theirs. The British conquest, on the other hand, "...is as crude as it was the first day." 55 The British conquerors remained always strangers, scornful of the natives and rapacious of their estates, "an endless prospect of new flights of birds of prey and passage," 56 who were coming to India to plunder and they were, afterwards, leaving, to enjoy the fruits of their plunder in England, as respected and prized gentlemen.

The lack of sympathy becomes now the infallible sign of tyranny, which does not refer anymore to the way a power is at first established, but to its failure or unwillingness to gradually veil the original violence by its benevolent practice and wise rule for the prosperity of the people; to the unwillingness of the conqueror to share practices, habits and sentiments with the original inhabitants and care for their prosperity. It becomes clear that Burke was not in principle an anti-imperialist or a political radical and the estimation to which he held the Indian society was based on traditionalist standards. These standards and values drove him to resist the voracity of the commercial interests and the arrogance of young adventurers, but his aim until the end was the reformation of the government of India. If this reformation, however, could not be accomplished, if the British were not able "to contrive some method of governing India well, which will not of necessity become the means of governing Great

\footnotetext{
51 Ibid., 125.

52 Alfred Cobban traces five instances where Burke supported the necessity of major social upheavals or "rebellions" against authority: the Glorious Revolution, the American War of independence, the struggle of the Corsican for freedom, the attempt of the Poles to preserve their national independence, and the various revolts against the minions of Warren Hastings. See Alfred Cobban, Edmund Burke and the Revolt Against the Eighteenth Century (London: Georges Allen and Unwin, 1960), 100. Gibbons in his Edmund Burke and Ireland would also add the case of Ireland.

53 In Burke's Correspondence we find the following telling statement regarding his defense of the people of India: "I have no cause in this business, but among a set of people who have none of your Lilies and Roses in their faces; but who are the images of the great pattern as well as you and I. I know what I am doing whether the white people like it or not." See The Correspondence, V, 255.

${ }^{54}$ Edmund Burke, Speech on Fox's East India Bill, 124.

55 Ibid.

56 Ibid.
} 
Britain ill," then, Burke thinks, "a ground is led for their eternal separation but none for sacrificing the people of that country to our constitution." 57

\section{Epilogue: Sympathy for Marie Antoinette}

I will conclude this article in the way I opened it, attempting a comparison between Burke's rhetoric on India and his rhetoric on the French Revolution. Burke himself explicitly associated his three major campaigns, the one against the Anglo-Irish ascendancy in Ireland, the one against Hastings in India and the one against Jacobinism in France. All three of Burke's opponents threatened the principles of constitutional government, which Burke considered as established in Great Britain, and all three of them tore apart aged-old customs and practices, which had made societies prosperous. ${ }^{58}$ I will attempt a more focused comparison, setting against the Indian rhetoric the famous Marie Antoinette abstract, where Burke made also use of the sentimentalist vocabulary ${ }^{59}$ and an ardent rhetoric, in order to arouse the sympathy of his readers. My purpose besides is rather to juxtapose the two.

What is noteworthy in Marie Antoinette's abstract is that Burke calls us to sympathize with a disreputable queen, and — as the Lords had done with regard to Hastings — with the oppressor rather than the oppressed. Burke thought highly of Marie Antoinette and tried hard to show that the French monarchy was not the incurable evil its enemies thought it was; that its blemishes could be reformed. Even in his own political circle, however, the Whigs, Burke was rather the minority. Philip Francis, for example, the person who led Hastings to jus tice and provided Burke with his extensive information about India, characterized Marie Antoinette as "Messalina" 60 and found Burke's insistence on her Beauty quite annoying. "If she be a perfect female character," Francis wrote, "you ought to take your ground upon her virtues. If she be the opposite it is ridiculous in any but a lover, to place her personal charms in opposition to her crimes." 61

The passage just quoted points to another crucial difference, for, if the emphasis of the Indian rhetoric is mostly on pain and the sublime, the emphasis of the Marie Antoinette abstract is on love and beauty. "It is now sixteen or seventeen years since I saw the queen of France, then the dauphiness, at Versailles," Burke writes, "and surely never lighted on this orb, which she hardly seemed to touch, a more delightful vision. I saw her just above the horizon, decorating and cheering the elevated sphere she just began to move in, glittering like the morning star, full of life, and splendor, and joy... I thought ten thousand swords must have leaped from their scabbards to avenge even a look that threatened her with insult. But the age of chivalry is gone." 62 While Marie Antoinette's passage forms a vindication of the polite Ancient Regime of France, the extensive passage from the Impeachment of Warren Hastings that we previously quoted, constitutes a rude and shocking attack on the rather debauched sensitivities of the English well-off Elite, the representatives of the English polite world. While Burke's rhetoric on India subverts the traditional or "orthodox" status hierarchies, ${ }^{63}$ Burke's rhetoric on the French Revolution comes to their rescue and, while

\footnotetext{
57 Ibid., 98.

58 See Edmund Burke, The Correspondence, VII, 553.

59 The events of October 6 , he observes in the beginning of this passage, "must shock [...] the moral taste of every well-born mind." The Writings, VIII, 117.

${ }^{60}$ Edmund Burke, The Correspondence, VI, 87.

61 Ibid., 86-87.

${ }^{62}$ Edmund Burke, The Writings, VIII, 126-127.

${ }^{63}$ I draw the concept from Will Kymlicka's Contemporary Political Philosophy (Oxford: Oxford University Press, 2002). The way Kymlicka exemplifies the concept is interesting: "This is a status hierarchy, which says that is better to be English than Irish; better to be Protestant than Catholic (and better to be a
} 
Burke's writings on India are "at every point upon the side of the future," 64 the attack on the French Revolution, with its nostalgia for the bygone age of chivalry, seems to be upon the side of the past.

\section{References}

Aristotle. The Complete Works of Aristotle: The Revised Oxford Translation. Edited by Johnathan Barnes. Princeton: Princeton University Press, 1984.

Burke, Edmund. The Writings and Speeches of Edmund Burke. Edited by Paul Langford. Oxford: Oxford University Press, 1981-2015.

. The Correspondence of Edmund Burke. Cambridge: Cambridge University Press, 19581970.

Select Works of Edmund Burke, vols. 1-3 and Miscellaneous Writings. Indianapolis: Liberty Fund, 1999.

Bourke, Richard. Empire and Revolution. Princeton: Princeton University Press, 2015.

Bromwich, David. The Intellectual Life of Burke. Cambridge: Cambridge University Press, 2014.

Canavan, Francis. The Political Reason of Edmund Burke. Durham: Duke University Press, 1960.

Cobban, Alfred. Edmund Burke and the Revolt against the Eighteenth Century. London: Georges Allen and Unwin, 1960.

Darwall, Stephen. "Empathy, Sympathy, Care.” Pbilosopbical Studies 89/2-3 (1998): 261-282.

Fuchs, Michel. Edmund Burke, Ireland and the Fashioning of Self. Oxford: Voltaire Foundation, 1996.

Gibbons, Luke. Edmund Burke and Ireland. Cambridge: Cambridge University Press, 2003.

Hume, David. A Treatise of Human Nature. Edited by L. A. Selby-Bigge. Oxford: Clarendon Press 1978.

Kohn, Margaret and O'Neill, Daniel I. "A Tale of Two Indias: Burke and Mill on Empire and Slavery in the West Indies and America." Political Theory 34/2 (2006): 192-228.

Kirk, Russell. Edmund Burke: A Genius Reconsidered. New York: Arlington House, 1967.

Kramnick, Isaac. The Rage of Edmund Burke. New York: Basic Books, 1977.

Kymlicka, Will. Contemporary Political Philosophy. An Introduction Oxford: Oxford University Press, 2002.

Laski, Harold. Political Thought in England from Locke to Bentham. New York: Holt, 1920.

Mehta, Uday Singh. Liberalism and Empire. Chicago and London: The University of Chicago Press, 1999.

Morrow, Glenn R. "The Significance of the Doctrine of Sympathy in Hume and Adam Smith." The Philosophical Review 32 (1923): 60-77.

O'Brien, Conor Cruise. The Great Melody: A Thematic Biography and Commented Anthology of Edmund Burke. Chicago: University of Chicago Press, 1992.

Christian of either sort, than Jewish or Muslim); better to be white than black or brown or yellow; better to be heterosexual than homosexual; and better to be able-bodied than disabled" (Contemporary Political Pbilosophy. An Introduction, 332). Most of the polarities mentioned engaged Burke's attention and, during his career, he fought for lower status groups as the Catholics, the Irish, the non-Christians and the Blacks. Even homosexuals found in Burke a defender; not of course, that he ever applauded homosexuality. How could he? He did, however, rose in the House of Commons to protest for the treatment of two homosexuals convicted in the pillory. See Isaac Kramnick, The Rage of Edmund Burke (New York: Basic Books, 1977), 84.

${ }^{64}$ Harold Laski, Political Thought in England from Locke to Bentham (New York: Holt, 1920), 226. 
Prior, James. Memoir of the Life and Character of the Right Hon. Edmund Burke : with Specimens of his Poetry and Letters and an Estimate of his Genius and Talents, compared with those of his Great Contemporaries. $2^{\text {nd }}$ edition, 2 volumes. London: Baldwin, Cradock and Joy, 1826.

Smith, Adam. The Theory of Moral Sentiments, London: H. G. Bohn, 1853.

Stanlis, Peter. Edmund Burke and the Natural Law. Ann Arbor: University of Michigan, 1958.

Strauss, Leo. Natural Right and History. Chicago: The University of Chicago Press, 1953.

Suleri, Sara. The Rhetoric of English India. Chicago and London: The University of Chicago Press, 1993.

Whelan, Frederik G. Edmund Burke and India: Political Morality and Empire. Pittsburgh: University of Pittsburgh Press, 1996. 